Feng, Huiyun and Kai He. 2018. "Prospect theory, operational code analysis, and risk-taking behavior: a new model of China's crisis behavior," Contemporary Politics 24 (2): 173-190.

\title{
Prospect Theory, Operational Code Analysis, and Risk-Taking \\ Behaviour: A New Model of China's Crisis Behaviour
}

\begin{abstract}
Authors' Bios:
Huiyun Feng is a Senior Lecturer in the School of Government and International Relations at Griffith University, Australia. She is a former Jennings Randolph Peace Scholar at United States Institute of Peace. Her publications have appeared in the European Journal of International Relations, Security Studies, The Pacific Review, International Politics, Chinese Journal of International Politics, and Asian Perspective. She is the author of Chinese Strategic Culture and Foreign Policy Decision-Making: Confucianism, Leadership and War (Routledge, 2007) and the co-author of Prospect Theory and Foreign Policy Analysis in the Asia Pacific: Rational Leaders and Risky Behavior (Routledge, 2013).
\end{abstract}

Kai He is Professor of International Relations at Griffith Asia Institute and Centre for Governance and Public Policy, Griffith University, Australia. He is currently an Australian Research Council (ARC) Future Fellow. He was a postdoctoral fellow in the Princeton-Harvard China and the World Program (2009-2010). He is the author of Institutional Balancing in the Asia Pacific: Economic Interdependence and China's Rise (Routledge, 2009), Prospect Theory and Foreign Policy Analysis in the Asia Pacific: Rational Leaders and Risky Behavior (coauthored with Huiyun Feng, Routledge, 2013), and China's Crisis Behavior: Political Survival and Foreign Policy (Cambridge, 2016). His peer-refereed articles have appeared in European Journal of International Relations, European Political Science Review, Review of International Studies, Security Studies, International Politics, Cooperation and Conflict, Asian Survey, The Pacific Review, Journal of Contemporary China, The Chinese Journal of International Politics, Asian Security, Asian Perspective, International Relations of the Asia Pacific, and Issues and Studies.

\section{Acknowledgements:}

The authors would like to thank Stephen Walker, editors, and anonymous reviewers of Comtemporary Politics for constructive comments and suggestions on this article.

\section{Funding Details:}


This project is supported by the Australian Research Council (Project ID: FT160100355) and the MacArthur Foundation (16-1512-150509-IPS). 


\title{
Prospect Theory, Operational Code Analysis, and Risk-Taking \\ Behaviour: A New Model of China's Crisis Behaviour
}

Huiyun Feng and Kai He

\begin{abstract}
Integrating prospect theory and operational code analysis, this paper introduces an innovative approach to studying the decision making of Chinese leaders during crises. The unique contribution of this paper is to adopt the methodology of operational code analysis to measure the domain of actions of policy makers in the application of prospect theory. We suggest that leaders' operational code beliefs can help us to identify in which domain of actions (gains or losses) leaders are located during crises. Xi Jinping experienced two notable foreign policy crises in 2014, the 'oil rig' crisis with Vietnam and the 'P-8 crisis' with the United States, which are examined in detail to illustrate Xi's operational code beliefs and risk-taking behaviour of 'confident accommodation' behaviour during crises. To test the process validity of integrating operational code analysis and prospect theory, Hu Jintao's operational code beliefs and crisis behaviour in 2011-2012 are then compared to Xi's beliefs and decisions in this study of China's crisis behaviour.
\end{abstract}

Chinese President Xi Jinping came to power after the $18^{\text {th }}$ Party Congress of the Chinese Communist Party (CCP) in 2012. In the $19^{\text {th }}$ Party Congress in 2017, Xi further consolidated his power by inserting 'Xi Jinping Thought' into the CCP constitution. Xi has become the most powerful Chinese leader since Mao Zedong (Philipps, 2017). China's foreign policy under Xi has undergone a dramatic transformation. The motto of 'keeping a low profile' or 'hiding strength and biding time' (taoguang yanghui), from the Deng Xiaoping era, was replaced by a more active policy of 'striving for achievement' (fenfa youwei) (Yan, 2014; Qin, 2014; Swaine, 2015a, 2015b; Lam, 2015b).

Xi proposed a new type of major power relations with the United States and other major powers in diplomatic undertakings and launched a 'charm offensive $2.0^{\prime}$ through massive 
economic investments and financial initiatives, such as the Belt and Road Initiative (BRI) and the establishment of the Asian Infrastructure Investment Bank (AIIB). Strategically, Xi also tightened military ties and energy cooperation with Russia in the aftermath of the Ukraine crisis. China's active involvement in global affairs consolidated its influence as seen from China's diplomatic engagement in the Middle East in early 2016 (Singh, 2016). Yet, China's neighbours and the United States grew deeply suspicious of China's land reclamation in the South China Sea.

As nuclear powers China and the United States will likely be deterred from large-scale military conflicts. However, given the differences in their respective strategic interests and ideologies, foreign policy crises seem unavoidable in future US-China relations. A foreign policy crisis refers to the existence of serious diplomatic friction between two countries, which will have a tremendous negative impact on their bilateral relations despite the absence of immediate military conflict and war (see James cited in Wilkenfeld, 2006, p. 111; He, 2016). A recent notable example of a foreign policy crisis between the two nations is the diplomatic row between the two over the Freedom of Navigation (FON) in the South China Sea (Perlez \& Hernández, $2015)^{1}$. If the US and China cannot manage such foreign policy crises effectively and peacefully, military conflicts may ensue and even escalate to an unintended war between the two states. Therefore, it is imperative to better understand China's crisis behaviour if policy makers in the Asia Pacific, especially the United States, intend to maneuver and manage a peaceful rise for China.

We apply a 'confident accommodation' risk-taking model to study the decision making of Chinese leaders during crises, which integrates prospect theory's risk-taking insights with an operational code analysis of beliefs. Prospect theory is a behavioural economic theory that explains how people make decisions under the condition of risks and uncertainties. One major 
argument is that people are more likely to take a risky decision when they are framed in a domain of losses. Otherwise, people are more likely to be risk-averse (Kahneman \& Tversky, 1979). Operational code analysis is a foreign policy analysis approach that highlights the importance of an agent's belief system regarding the exercise of power in making decisions (Leites, 1951, 1953; George, 1969; Holsti, 1977; Walker,1977).

Applying prospect theory, we argue that Chinese leaders are more likely to avoid risks and seek accommodation in de-escalating a crisis when they are in a domain of gains, i.e., when they feel strong and have confidence in their power to control events. Conversely, they are more likely to take risks in escalating a crisis when they are framed in a domain of losses, i.e., when they feel weak and less confident in their power during crises (He, 2016). The unique contribution of this paper is employing the psychological analysis of operational code beliefs to measure the domain of actions of policy makers specified by prospect theory. We hypothesise that operational code beliefs will help us identify an agent's domain of actions during crises. If a state's leaders have a belief that they can exercise strong control over historical events (the P-4 belief in operational code analysis), they are more likely to be located in a domain of gains during crises and be relatively risk-averse in making decisions. If they have a relatively weak P-4 belief in historical control, then they more likely to be in a domain of losses and make riskacceptant decisions. $^{2}$

Using operational code analysis in the study of Chinese foreign policy, one caveat is worth noting. We assume that Chinese top leaders, such as Jing Zemin, $\mathrm{Hu}$ Jintao, and Xi Jinping, play the most important role in making foreign policy decisions in China. We acknowledge that top leaders are not the only actor in Chinese foreign policy making process. Other actors and factors, such as factional struggles, nationalism, bureaucratic politics, might 
also influence China's foreign policy. However, we make this 'leader-first' assumption in this research for two reasons.

First, in China's hierarchical political system, Chinese top leaders are always the ones who make the final call in foreign policy. As Wang Guanya, one Chinese top diplomat and then Vice Foreign Minister, mentioned, 'control of policy and decision making in China's foreign affairs has always been resided with the country's top leaders' (cited by Kuhn, 2010, p. 376). Although it is not to deny potential influences of other factors and actors in foreign policy, we suggest that examining leaders' belief systems is a legitimate approach in the study of Chinese foreign policy. In addition, given Xi's paramount political position in Chinese political hierarchy in the next five to ten years, it is a worthy effort to examine Xi's beliefs and China's foreign policy. ${ }^{3}$ Both prospect theory and operational code analysis can focus on an individual's decision-making process. This research, therefore, can serve as a preliminary analytical probe to explore Xi's beliefs and policy patterns in the future. It can also encourage other scholars to propose different approaches in identifying the sources of Xi's beliefs in his personality or within Chinese political culture, which will enrich future studies of Chinese foreign policy.

It is worth noting that although we focus on Xi's beliefs as expressed in his public statements, these beliefs may well also reflect the beliefs of others, i.e., his statements may reflect shared beliefs within the Chinese government. Depending on the power distribution among the CCP political elites, which may vary from situation to situation, the statements may or may not reflect his personal beliefs or instead a consensus between $\mathrm{Xi}$ and other members of the CCP's inner circle after deliberations and bargaining among them to reach a decision. In the latter case, $\mathrm{Xi}$ would be merely a 'focal actor' who acts as a conduit to communicate joint decisions by a group or organization (e.g., the Soviet Politburo) rather than a predominant leader 
(e.g., Stalin) whose beliefs govern the decision (Achen, 1988; M. Hermann, 1974; Leites, 1953). In either case key operational code beliefs in Xi's public statements still frame (define) the decision-making situation as located in the domain of gains or the domain of losses (P-4) plus diagnose the situation as a hostile (conflict) or friendly (cooperation) situation (P-1) and prescribe a propensity to respond (I-1) with a conflict, mixed, or cooperation strategy (George, 1969; Holsti, 1977; Walker, 1977).

There are four sections in the paper. First we briefly examine China's puzzling behaviour under Xi Jinping in 2014: during the oil rig crisis with Vietnam and the P-8 incident with the United States. We suggest that China's 'compromising behaviour', to a different degree, in both crises cannot be explained by either Xi's weak power status or by failed coordination among Chinese bureaucracies. Second, we propose a 'confident compromise' model by integrating prospect theory and operational code analysis. Third, we analyse Xi Jinping's operational code beliefs before the two crises and use the P-4 belief to measure Xi's domain of actions according to prospect theory. We argue that Xi's P-4 belief shows that he was in a domain of gains before the two 2014 foreign policy crises. This is why he chose a risk-averse option to de-escalate both crises. We conclude by discussing some theoretical, methodological and empirical implications of this research for empirical studies of Chinese foreign policy in particular and theoretical studies of foreign policy analysis in general. We also caution that Xi's behaviour is best understood as explained theoretically by the interaction between the situational frame of gains or losses from prospect theory and key beliefs from operational code theory rather than one model or the other.

\section{Two Crises and One Puzzle}


In 2014, Xi experienced two short, but serious, foreign policy crises, the 'oil rig crisis' with Vietnam from May to July and the 'P-8 incident' with the United States on August 19 (see He, 2016). In both crises China was in an 'initiator' role to a certain extent. The 'oil rig crisis' was triggered by an oil rig placement by China's state-owned oil company-China National Offshore Oil Corporation (CNOOC) - in waters near the Paracel Islands in the South China Sea and 120nm from Vietnam's coastline. Since both China and Vietnam claim sovereignty over the Paracels, China's oil rig move was widely interpreted as a provocation regarding the status quo.

Consequently, CNOOC's action caused serious semi-military confrontations between China and Vietnam over the oil rig. Anti-Chinese protests and riots broke out in Vietnam, and many Chinese and even Taiwanese-owned properties were burned down or damaged by Vietnamese nationalist protesters (Perlez \& Bradshermay, 2014). The Chinese government dispatched State Councilor Yang Jiechi to visit Vietnam in mid-June in order to manage the crisis. On July 16, China withdrew the oil rig from the Paracel area. It was almost one month earlier than expected, because the CNOOC had announced that its oil rig would finish drilling operation in mid-August. The 'oil rig' crisis ended dramatically, just like its surprising onset.

When the P-8 crisis happened in August 2014, a Chinese fighter J-11 intercepted two US Navy P-3 and P-8 planes that were conducting reconnaissance missions over the South China Sea about 220km from China's Hainan island. According to US sources, the Chinese jet made several passes and crossed under a US P-8 plane with one pass having only 50-100 feet of separation. On August 22, the US Department of Defense registered strong concerns to highranking Chinese diplomats over the unsafe and unprofessional intercept, which posed a risk to the safety and wellbeing of the aircrew (Lyle, 2014). Since the US official statement only included the P-8 plane and not the P-3 aircraft in the incident, the crisis was called the $\mathrm{P}-8$ 
incident'. The reason to treat the P-8 incident as a crisis is due to its similarity with the 2001 'EP3 incident' when one Chinese fighter intercepted a US EP-3 surveillance plane that ended with a tragic midair collision over the South China Sea.

Chinese policy reactions in both crises are puzzling in two aspects: first, we do not know why China initiated these two crises in the first place. Second and more importantly, why did China choose to 'accommodate' or even 'compromise' and de-escalate in both crises? In this research, we do not investigate the origins of the two crises. Instead, we focus on the second puzzle-China's policy choices after the outbreak of the crisis. As mentioned above, China withdrew its oil rig one month before schedule after the diplomatic flare-ups with Vietnam. In the P-8 crisis after a round of strong diplomatic protests, China started to negotiate with the United States the 'rules of the road' in the airspace. It is worth emphasizing that some scholars might not see China's behaviours as a 'compromise', which is also understandable because China was initially assertive in both crises.

However, China indeed chose to de-escalate both crises and also tuned down its opposition toward both Vietnam and the United States after the crises. For example, after US FON activities in the South China Sea in October, 2015 and in January, 2016 China only voiced some routine diplomatic protests. It is also reported that in February, 2016 China deployed missile batteries on Woody Island in the Paracels, which has been under Chinese control for decades but is also claimed by Vietnam. The United States criticised China's action, but China dismissed the concerns over missile deployment in the South China Sea by saying China's behaviour was motivated by self-defence (see Hohammed \& Wu, 2016; Wen \& Murdoch, 2016).

There are two popular explanations for Chinese accommodative behaviour in these two 
crises. One is to suggest that Xi's de facto control of power in both domestic politics and foreign affairs is weak in nature, i.e., Chinese foreign policy under Xi's leadership is like a 'paper tiger' - strong outside but weak inside. It is why China had to compromise during the two crises. This explanation also accounts for why China did not participate in military actions against ISIS even after its own citizen was executed as a hostage in late 2015 (Keck, 2014; Dibb, 2015; Lam, 2015a). Another explanation called 'coordination failure' treats China's contradictory foreign policy as the result of failed coordination between the central government, local authority, and different bureaucracies.

Thus, one leading IR scholar in Beijing suggests that the oil rig crisis not only caught the outside world off-guard, but also surprised the Chinese Foreign Ministry to a certain extent (Personal interview in Beijing in June, 2014). The lack of coordination among various Chinese government agencies involved in the South China Sea is an open secret. If this were the case, then the 'oil rig crisis' might be a result of 'nine dragons stirring up the sea' instead of a deliberative strategic move (ICG, 2012; Jakobson, 2014). Similarly, some scholars indicate that the P-8 crisis was actually triggered by China's local 'rogue' military officers, who made the provocative and dangerous actions against the United States unilaterally (Pei, 2014).

Admittedly, these two crises happened quite recently in 2014, and there are still a lot of unknown issues about them as a result of limited resources and information. Although the above arguments might capture some parts of the truth, they present two analytical problems. The former argument seems correct in revealing the nature of Xi's policy orientation i.e., to give preference to compromise and accommodation over escalation and conflict during crises, but its reasoning is problematic. Its key assumption is Xi's weak power status within the Communist Party (CCP). This is much like M. Taylor Fravel's 'regime insecurity' thesis, which argues 
similarly that the higher the regime insecurity in the CCP, the more likely it is for the Chinese government to choose to compromise toward the outside (Fravel, 2008).

However, it is well known that Xi had successfully consolidated his power inside the CCP soon after he came to power. Using the anti-corruption campaign, he successfully got rid of the potential challenges to his leadership, including the Princelings of Bo Xilai and the Military tigers Guo Boxiong and Xu Caihou. Unlike his predecessor Hu Jintao, Xi was able to secure all the important posts within the Party, the government, and the military. After meeting with Xi during the APEC meeting in late 2014, President Obama publicly stated that 'he (Xi) has consolidated power faster and more comprehensively than probably anybody since Deng Xiaoping and everybody's been impressed by his...clout inside of China after only a year and a half or two years' (The Straits Times, 2014; also Economy, 2014). There is also clear evidence that Xi has established his position as the 'paramount leader' in the CCP system. In 2016, Xi was claimed to become the 'core leader' of the CCP. As mentioned before, Xi wrote his name into the CCP constitution at the $19^{\text {th }}$ Party Congress in 2017. It signifies Xi's equal status with Mao in the CCP history. Therefore, Xi likely exerts considerable personal control during crises and exercises real power in the CCP system.

'Coordination failure' might be able to account for the onset of the crises, but not the reaction from Xi after the initial stage of the crises. Even if different bureaucratic interests within the Chinese government or between the civil and the military branches caused China to become the initiators in both cases, when the crises came to the attention of the foreign policy establishment and the central government, Xi became the ultimate decision maker for the crises. Like the previous weak Xi argument, the 'coordination failure' argument assumes the weakness of Chinese bureaucracies or key decision-making bodies in dealing with the crises. It tries to 
paint a picture that incompetence leaves the Chinese government no choice but to compromise during crises. This interpretation underestimates the efficiency of the hierarchical Chinese political system and China's foreign policy decision-making bodies.

$\mathrm{Xi}$ is well aware of the problems of bureaucratic politics, as he created a National Security Commission in November, 2013 to facilitate and improve bureaucratic coordination inside the government on security-related issues (Hu, 2016; You, 2016; Erickson \& Liff, 2016). Because the maritime crisis and the P-8 crisis are of relatively high sensitivity and intensity, they will directly reach the attention of the central government. Thus, the policy process will be more top-down over these issues. Therefore, the 'coordination failure' argument seems difficult and even irrelevant in accounting for Xi's crisis behaviour in mid-2014. More importantly, Xi's accommodation-oriented policy making is not unique for only these two crises in 2014. If we count the two US FON missions in late 2015 and early 2016 as foreign policy crises, Xi also chose to de-escalate the FON crises. Obviously, Xi's accommodative approach in these foreign policy crises cannot simply be attributed to the incompetent bureaucracies of the Chinese government.

\section{'Confident Accommodation'_-Prospect Theory and Operational Code Analysis}

To better understand Xi's accommodative behaviour in foreign policy crises, we suggest a new risk-taking pattern: confident accommodation. Instead of Xi's weakness in power, or the weakness of the Chinese bureaucracy, it is Xi's strong confidence in power and control that encourages him to de-escalate the crises. This 'confident accommodation' argument is based on prospect theory, a Nobel-Prize-winning behavioural psychology and economics theory. Prospect theory was introduced by Daniel Kahneman and Amos Tversky through laboratory experiments 
(Kahneman \& Tversky, 1979). It is rooted in cognitive psychology and has become 'the leading alternative to expected utility as a theory of choice under conditions of risk' (Levy, 1996).

Kahneman and Tversky find that people systematically violate the behavioural expectations that a rational choice approach assumes, which is to maximise expected utilities in making decisions. Prospect theory suggests that most people are risk-averse when confronted with choices between gains, but more likely to take risks or be risk-acceptant when faced with losses. In other words, people interpret their situation for making choices as located either in a domain of gains or losses, which influences how they behave in terms of their risk orientation. It is called the framing effect: how the situation is framed determines the actor's domains of action with respect to a reference point of gains or losses, which consequentially influence his/her risk propensity and behaviour.

Applying prospect theory, we suggest that Xi has acted in a domain of gains during crises after his swift and successful consolidation of power inside the CCP. The strong confidence in his power is the driving force for him to choose a risk-averse policy and seek to accommodate and de-escalate foreign policy crises. Thus, our argument directly challenges the power weakness and bureaucracy weakness arguments to suggest that the stronger Xi's power is, the more likely it is for him to seek accommodation with others during crises. Here the risk refers to the probability of military conflict triggered by foreign policy crises. To escalate a crisis is seen as a risk-acceptant behaviour while to de-escalate a crisis is risk-averse in nature.

In prospect theory the 'reference point' is an artificial analytical tool for scholars to evaluate individuals' domains of action in making decisions. The assumption is that people tend to evaluate choices with respect to a reference point. If people see themselves as above the reference point, they are framed in a domain of gains. If people are located below the reference 
point, they are framed in a domain of losses. Therefore, how to set the reference point is very significant in determining one's domains and a major challenge for applying prospect theory to real-life political events. So far, there is no generally accepted theory of framing or setting of the reference point; therefore, scholars have introduced different techniques to pragmatically set a reference point for determining an actor's domain of gains or losses (Levy, 1997). Jonathan Mercer suggests that there are five prevailing methods for setting reference points: the status quo, aspiration level, heuristics, analogies, and emotions (Mercer, 2005).

However, no matter which method is chosen, prospect theory scholars normally rely on a qualitative approach to measure the reference point. For example, Rose McDermott set the status quo as the reference point and employed case studies, contextual analyses, and interviews to measure the domain of actions for US policy makers in her book, Risk-taking in international relations: Prospect theory in post-war American foreign policy (McDermott, 1998). In a similar vein, Jeff Taliaferro also relies on archival analysis to examine why great powers took risks to get involved in unnecessary conflicts and interventions in the periphery (Taliaferro, 2004).

Although the qualitative measurement of the domain of actions is the prevailing approach among prospect theory scholars, it is less promising in the study of Chinese President Xi's crisis behaviour. $\mathrm{Xi}$ is a new leader who has been in power officially for only five years. There is a significant limitation on the amount of sources and information available for scholars to conduct in-depth qualitative analyses of Xi's foreign policy. The opaque nature of the Chinese decisionmaking process also precludes scholars from conducting reliable interviews with Chinese officials. With the anti-corruption campaign and a new wave of suspicion of Western influence, scholars and analysts are less willing these days to be interviewed or to offer their opinions publicly. 
In this paper we introduce operational code analysis to measure Xi's domain of actions during crises. Operational code analysis is a psychological approach in leadership studies and has recently developed as a neobehavioural approach in foreign policy analysis. It suggests that we can make sense of foreign policy decision making by examining the leader's operational code belief system. There are two types of beliefs: philosophical beliefs 'about the nature of the political universe', that represent the external world of events and instrumental beliefs for 'making decisions about the exercise of power vs. other actors in the political universe', which prescribe possible strategies, tactics, and moves (Walker, 2011, p. 6).

Built on Nathan Leites' prototypical studies of the Bolshevik operational code in the 1950s, Alexander George developed a methodology of operational code analysis by suggesting ten questions as a tool to gauge any individual's philosophical and instrumental belief system (Leites, 1951; George, 1969; also Schafer \& Walker, 2006a). These questions are as follows:

\section{Philosophical Beliefs}

P-1 What is the 'essential' nature of political life? Is the political universe essentially one of harmony or conflict? What is the fundamental character of one's political opponents?

P-2 What are the prospects for the eventual realization of one's fundamental values and aspirations? Can one be optimistic, or must one be pessimistic on this score; and in what respects the one and/or the other?

P-3 Is the political future predictable? In what sense and to what extent?

P-4 How much 'control' or 'mastery' can one have over historical development? What is one's role in 'moving' and 'shaping' history in the desired direction?

P-5 What is the role of 'chance' in human affairs and in historical development?

\section{Instrumental Beliefs}

I-1 What is the best approach for selecting goals or objectives for political action?

I-2 How are the goals of action pursued most effectively?

I-3 How are the risks of political action calculated, controlled, and accepted?

I-4 What is the best 'timing' of action to advance one's interests?

I-5 What is the utility and role of different means for advancing one's interests? 
Ole Holsti and Stephen Walker have typologised different types of belief systems with some key beliefs, such as (P-1) nature of the political universe; (I-1) strategic approach to goals; and (P-4) ability to control historical development (Holsti, 1977; Walker, 1977; Walker, 1983). The operational code analysis has become a useful approach in the field of foreign policy analysis. Different answers by different leaders to George's ten questions provide different diagnostic and prescriptive heuristics for exercising power during crisis situations when the presence of external stress and the absence of complete and accurate information makes a leader's pre-existing beliefs more likely to be influential (Holsti, 1977).

Under these conditions a leader's philosophical beliefs influence the definition of the situation as hostile or friendly (P-1) and the power distribution as symmetrical or asymmetrical (P-4); instrumental beliefs (I-1) prescribe a strategy in making foreign policy decisions (Holsti, 1977; Walker, 1977, 1983; Walker \& Schafer, 2010). Our model focuses on the interaction between the key belief regarding historical control (P-4) and the other two key beliefs (P-1 and I1), as an agent defines the situation as hostile or friendly (P-1) and selects a strategy (I-1). While P-4 does not necessarily influence which strategy (cooperation, mixed, or conflict) is selected, we hypothesise that it does interact with I-1 to constrain the level of risk with which a strategy is implemented.

Therefore, in this analysis of China's foreign policy decisions we emphasise the importance of the P-4 belief - the ability to control historical development. We suggest that the P-4 belief can reflect a leader's confidence in controlling power in both domestic and international domains. We set the status quo of Xi's P-4 belief before a crisis as a reference point. Then we examine the changes of Xi's P-4 belief during and after a crisis. If Xi's P-4 belief moves below the status quo, then it suggests that $\mathrm{Xi}$ is framed in a domain of losses. If $\mathrm{Xi}$ 's P-4 
belief moves above the status quo, then $\mathrm{Xi}$ is framed in a domain of gains. Depending on the frame, we hypothesise that the strategy selected will be more risky in the domain of losses and less risky in the domain of gains.

In previous operational code studies, the P-4 belief is often aggregated over time and treated as a stable belief across situations. However, we suggest that stability is not always the case. Some scholars have linked leaders' P-4 belief with policy behaviour in their research. For example, Mark Schafer, Sam Robison, and Bradley Aldrich used operational code analysis, especially the P-4 belief, to test the 'frustration-aggression' hypothesis in the 1916 Easter Rising in Ireland. As they argue, the P-4 belief 'looks at the actor's sense of control in politics'. If 'one cannot reach a desirable goal at a particular time in a behavior sequence because of the actions of some external entity', he or she will be more likely to feel frustrated (see Schafer, Robison, \& Aldrich, 2006, pp. 68-70). ${ }^{4}$

In our research this frustration is also operationalised by the P-4 belief change; a decrease in P-4 is the mechanism that will define a domain of losses for leaders during crises. Our selection of the P-4 belief as the measure of leaders' domain of action is a preliminary probe that is open to discussions and debates from other scholars. On the one hand, the P-4 belief is an integrated measure of a leader's belief in the control of historical development, which may be influenced by many factors, including both domestic and international challenges that are not directly measured. On the other hand, this innovative approach is parsimonious and has the potential to be generalised to other leaders beyond China.

Traditionally, operational code analysis relies on qualitative methods, i.e., the interpretation of interviews and written texts analysis, to measure leaders' beliefs. Since the 1970s, scholars have gradually developed the Verbs in Context System (VICS) and Profiler Plus-computer- 
based content analysis programs - for scientifically 'retrieving and analyzing a leader's operational code beliefs' (Walker, Shafer, \& Young, 2003, pp. 215-216). VICS is a computer software program for content analysis based on verbs in a leader's public statements and speeches. According to George's ten questions about philosophical and instrumental beliefs, VICS codes the verbs in leaders' speeches in order to construct indices of a leader's view of the political universe and preferences for strategies. Operational code analysis and the VICS indices have been widely used by many scholars in the field of foreign policy analysis and political psychology (see Walker, Schafer, \& Young, 1998; Feng, 2005; Malici \& Malici, 2005; Marfleet, 2000; Schafer \& Walker, 2006b).

\section{Research Design and Results}

We have collected Xi Jinping's public statements and speeches on foreign affairs from 2008 to 2015. All these speeches and statements are from the Chinese Foreign Affairs Ministry's website. They are published and translated in English by the Chinese government. Since our operational code analysis aims to test Chinese leaders' belief systems and foreign policy decisions, the speeches from the Chinese Foreign Affairs website are most authoritative in nature compared to other sources. As previously mentioned, Xi officially came to power in late 2012 although he had served as the Vice President in charge of foreign policy in 2007. The two crises we analyse happened in mid-2014. From 2013 to 2015, Xi had actually been in power as the top leader in the Chinese political hierarchy for three years. Therefore, we use 2012 as the cutting point for setting the status quo reference point of P-4. We divide Xi's tenure in power into four time periods: Period 1 (before coming to power, 2008-2012), Period 2 (2013, the first year in power), Period 3 (2014, crisis-year), and Period 4 (2015, post-crisis). Xi's P-4 belief in Period 1 
is the 'status quo' reference point, because it reflects Xi's initial belief in his power (historical control). We compare Xi's P-4 beliefs in these four time periods, especially between Period 3 (crisis-year) and Period 1 (status quo). If Xi's P-4 belief moves below the reference point (Period 1), it means that $\mathrm{Xi}$ is framed in a domain of losses. Otherwise, $\mathrm{Xi}$ behaves in a domain of gains.

The speeches are usually longer than 1,000 words. There are a total of 73 speeches. There are 26 speeches in Period 1, ten speeches in Period 2, 21 speeches in Period 3, and 16 speeches in Period 4. We used Profiler Plus to code the VICS indices in Xi's speeches and to quantify the key operational code beliefs for Xi. Then an ANOVA test was conducted to identify belief differences across these four periods, and the Tukey post-hoc test was used for the multiple comparisons of the P-4 values. Table 1 summarises the mean comparisons of Xi's P-4 (historical control) beliefs across these four time periods.

[Table 1. Here]

In Table 1 we can see that Xi's P-4 value before 2013 (Period 1) is lower than all other three periods. It means that Xi grew more confident in his belief regarding 'historical control' after he assumed the top position in late 2012. However, the statistical test shows that Xi's P-4 value in Period 1 is not significantly different from that in Period 2. Since Period 2 is the first year of Xi's leadership, it is understandable that Xi will need some time to consolidate his power (particularly his anti-corruption campaign against major tigers). Interestingly, Xi's P-4 values in Period 3 and 4 are statistically different from the one in Period 1. It indicates that Xi's confidence in his power significantly increased in 2014 and $2015(\mathrm{p}<.05)$.

As mentioned earlier, the year 2014 is the crisis year for Xi when both the 'oil rig crisis' with Vietnam and the 'P-8 crisis' with the United States took place in the middle of the year. Therefore, Xi's P-4 belief in 2014 can serve as a good indicator of Xi's domain of actions during 
these crises. Our operational code analysis shows that Xi's P-4 belief (historical control) in 2014 is significantly higher than the one in Period 1 (the status quo). Therefore, we can infer that Xi was framed in a domain of gains during these two crises in 2014.

In order to confirm the validity of using operational code analysis in measuring Chinese leaders' domain of actions during crises, we examined the operational code beliefs of Hu Jintao, Xi's predecessor, during two other crises in 2012. In 2012, China underwent two intense foreign policy crises with the Philippines over the Scarborough Shoal and with Japan over the Senkaku/Diaoyu islands. China's policy in both crises was characterised as 'hardline' and 'assertive' in nature (Perlez, 2012a, 2012b; Sutter \& Huang, 2012; Neuman, 2012; The Economist, 2013a, 2013b; He, 2016). Since the 'risk' of crisis behaviour is measured by the probability of military conflict, China's policy in the 2012 crises is apparently risk-acceptant. If our previous discussion of operational code beliefs and prospect theory is correct, we should see that $\mathrm{Hu}$ Jintao, then top Chinese leader in 2012, was framed in a domain of losses.

[Table 2. Here]

Like our operational code analysis on $\mathrm{Xi}$, we collected Hu's public statements and speeches on foreign affairs in 2011 and 2012 respectively. We have ten speeches in 2011 and six speeches in 2012. Then we ran Profiler Plus to code the VICS indices for Hu and compare Hu's operational code beliefs between 2011 and 2012. Table 2 contains our ANOVA results. The mean value of Hu's P-4 belief (historical control) in 2012 is .14 and his P-4 value in 2011 is .28. The difference of P-4 value for Hu between 2011 and 2012 is statistically significant. It shows that Hu's P-4 belief in historical control dropped significantly in 2012 compared with his P-4 belief in 2011.

This significant decrease in the P-4 belief indicates that Hu was framed in a domain of 
losses in 2012 when China was involved in foreign policy crises with the Philippines over the Scarborough Shoal and with Japan over Diaoyu/Senkaku islands. According to prospect theory, $\mathrm{Hu}$ is more likely to take risk-acceptant actions in a domain of losses. This result not only explains why China adopted hardline policies toward the Philippines and Japan in 2012, but also supports the validity of using operational code analysis to examine Chinese leaders' domain of actions in foreign policy crises.

The year 2012 was a critical one for Chinese domestic politics, because the CCP experienced a once-a-decade leadership transition from $\mathrm{Hu}$ to $\mathrm{Xi}$ at the $18^{\text {th }}$ Party Congress. Moreover, people may argue that due to historical reasons, the Diaoyu/Senkaku dispute between China and Japan could arouse more nationalistic emotions for Chinese leaders than other foreign policy crises, such as the oil rig crisis with Vietnam and the P-4 incident with the US. These analyses are all correct. It is why Hu seemingly had no choice but to take a risky policy to cope with these challenges.

As we mentioned before, the P-4 belief is an integrated index to measure a leader's belief in 'control of historical development', which can entail many historical and psychological factors, including nationalism and a domestic power struggle. If a leader can handle these challenges masterfully, it will be reflected as a high P-4 belief index. Otherwise, the P-4 belief will be low. Therefore, our approach to using the P-4 belief to measure a leader's domain of action does not deny other factors' influences in foreign policy. Instead, the P-4 belief is an integrated but simplified measure of these challenges for a leader's belief system.

\section{Xi's Confident Accommodation}

According to prospect theory, $\mathrm{Xi}$ is more likely in a domain of gains to choose a risk- 
averse policy to seek accommodation and de-escalate the crises. Recalling our operational code analysis on Xi's P-4 belief, Xi was framed in a domain of gains because Xi's P-4 belief is higher in the crisis year (2014) than the status quo value. As discussed earlier, China voluntarily withdrew the oil rig one month before schedule in the oil rig crisis with Vietnam. Compared with China's strong reactions to the Philippine in the 'Scarborough Shoal' dispute and against Japan in the Diaoyu/Senkaku crisis in 2012, Xi's policy in 2014 can be seen as serious accommodation toward Vietnam. In the P-8 incident with the United States, besides procedural business-as-usual protests, China's willingness to negotiate the 'rules of the road' was pragmatic accommodative behaviour and posture toward the United States. Although there is no reliable information to confirm directly Xi's role in the P-8 crisis, it is safe to say that without Xi's endorsement, the Chinese military could not have behaved so pragmatically toward the United States after the P-8 crisis.

Given Xi's strong position regarding the establishment of the Air Defense Identification Zone over the East China Sea in November, 2013, it seems a bit surprising that Xi's crisis behaviour turned less coercive in 2014 . The operational code analysis in this paper shows that Xi became more confident in power control and historical development in 2014, one year after his assumption of power. It indicates that Xi had successfully consolidated his power in the CCP and acted in a domain of gains when the two 2014 crises took place.

Some key events also support this finding from operational code analysis. Xi waged a large-scale and still ongoing anti-corruption campaign in China soon after he came to power. Xi was able to launch this unprecedented 'anti-corruption campaign' almost immediately after assuming office. It indicates that $\mathrm{Xi}$ was in a much stronger position at the outset of his tenure compared to Hu Jintao (or even Hu's predecessor Jiang Zemin). Since it began in 2012, the anti- 
corruption campaign has already netted more than 160 'tigers' whose rank is above or equivalent to that of the deputy provincial or deputy ministerial level, and more than 1400 'flies' or lowerlevel officials in early 2016 (Jakes, 2016). Besides cleaning up the CCP, Xi also consolidated his leadership and eliminated political rivals through the anti-corruption campaign. Zhou Yongkang, a former member of the Politburo Standing Committee, was arrested in late 2014. Zhou was the most senior Chinese leader to be prosecuted for corruption since the foundation of the PRC (Lague, Kim, \& Zhu, 2014).

As Roderick MacFarquhar (2015), a leading scholar in Chinese politics, suggests, 'what is widely accepted among China hands is that $\mathrm{Xi}$ is the most powerful leader of China since Deng Xiaoping, with a developing personality cult. $\mathrm{Xi}$ is not primus inter pares like Jiang and $\mathrm{Hu}$; he is simply primus...In fact, $\mathrm{Xi}$ is arguably even more powerful than Deng was'. MacFarquhar's prediction about Xi's power in 2015 is further confirmed by the political victory of Xi at the $19^{\text {th }}$ Party Congress in 2017. Besides inserting his name into the CCP constitution as mentioned before, Xi also broke another unwritten rule in the $\mathrm{CCP}$ tradition. Xi did not name his successor at the $19^{\text {th }}$ Party Congress. According to the Chinese political tradition set by Deng Xiaoping, Xi should name his successor in his second term in order to ensure a smooth leadership transition after five years. However, $\mathrm{Xi}$ apparently refused to do so this time. It is reported that Xi might intend to remain in power for more than two terms (ten years), which is against the CCP tradition after Deng (Buckley, 2017).

Xi's increasing confidence in power is also seen in his proactive foreign policy toward the outside world. Xi has promoted a new type of major power relations in managing China's bilateral relations with major powers in the region. In June 2013, Obama met Xi informally in Sunnylands, California, where they agreed to establish a new type of strategic cooperation. In 
October 2013, Xi delivered a speech at the foreign affairs conference of the CCP and articulated a foreign policy strategy of 'striving for achievement'. In May, 2014 Xi delivered a speech at the Conference on Interaction and Confidence Building Measures in Asia (CICA), and called for Asian problems to be solved by Asians. Xi's articulation of an active diplomacy might be a counter move in response to Obama's April 'containment' tour of four Asian countries surrounding China, namely Japan, South Korea, Malaysia, and the Philippines (Landler, 2014).

This analysis is not to suggest that international pressure on $\mathrm{Xi}$ was low during the two crises in 2014. On the contrary, Chinese leaders faced tremendous international criticisms in 2014, especially during the oil rig crisis. However, Xi was able to successfully stabilise bilateral relations with the United States and other major powers in the region through active foreign policy initiatives. For example, China reached free trade agreements with Australia and South Korea in late 2014. In October, the Asian Infrastructure Investment Bank (AIIB) was established in Beijing with 21 countries signed onto the agreement. Since China is the initiator and the largest stakeholder, the AIIB is widely seen as a rival financial institution to the World Bank and Asian Development Bank led by the United States (Reuters, 2014).

Given the domestic and international situations, it is reasonable to conclude that Xi was more likely to be framed in a domain of gains during the two crises in 2014. So Xi's accommodative behaviour during the two crises is understandable, because Xi was not in a position with an incentive to take risks to escalate crises. Thus, China withdrew its oil rig in the South China Sea one month earlier than expected, and the Chinese military showed flexibility in negotiating the 'rules of the road' with the United States after the P-8 crisis.

Finally, this 'confident accommodation' argument remains a 'plausibility probe', because both crises are relatively new with not enough information or evidence available to fully 
substantiate the model. Although operational code analysis illustrates a new approach to measuring Xi's domain of actions during crises, more data is needed to further test the reliability and validity of this method. We hope this research tool can shed some light on studies of China's crisis behaviour under Xi's leadership in particular as well as demonstrate the integration of prospect theory and operational code analysis in general (e.g., He \& Feng, 2011).

\section{Conclusion}

In this paper we have examined the patterns of Xi's crisis behaviour through an in-depth analysis of two crises, the oil rig crisis with Vietnam and the P-8 crisis with the United States in 2014. Challenging the prevailing arguments emphasising Xi's weak power and China's weak bureaucracy, we suggest that Xi's accommodation policies in both crises were driven by strong confidence in his power. Through integrating prospect theory and operational code analysis, we examined Xi's operational code belief in control over historical development (P-4) across four time periods. The results show that Xi became more confident over his historical control in 2014 in comparison with the period before he came to power. It indicates that $\mathrm{Xi}$ acted in a domain of gains during the 2014 crises, thus adopting an accommodative policy to avoid the risks of escalation into military conflicts.

$\mathrm{Xi}$ is a strong leader but still faces challenges even within the party. For example, on March 4, 2016 a mysterious open letter calling for Xi to resign appeared on Wujie News, a government-owned news website. Although the letter was removed quickly and the government also started a crackdown and serious investigation, it indicates that $\mathrm{Xi}$ will still face various challenges from different factions inside the CCP (Rauhala \& Xu, 2016). Although it is true that Xi has further strengthened his power at the $19^{\text {th }}$ Party Congress in 2017 , it does not mean that he 
is unchallengeable in the CCP system. Xi's leadership authority might become vulnerable to influence and pressure from the military and the outside world if foreign policy crises occur. Xi may adopt risk-acceptant policies as a political tool to establish or reconsolidate his authority in the CCP. If so, we also expect Xi's P-4 belief index to decrease, as Hu Jintao's P-4 belief did, which would be a good future validity test of the use of prospect theory and operational coda analysis in concert with one another.

Our research has significant implications for the academic and policy communities. First, our model integrates two academic approaches, prospect theory and operational code analysis, to explain China's foreign policy. It not only offers a new path for future research on China's foreign policy; it also advances the applications of prospect theory and operational code analysis in the subfield of Foreign Policy Analysis. Methodologically, our use of operational code analysis is an innovative method to measure the 'domain of actions' in prospect theory. If other scholars should challenge the validity of the P-4 belief from operational code analysis in measuring the 'domain of actions', then we encourage them as well to propose their new methods and approaches for comparative validity tests with the P-4 index.

Second, the significance for the policy community is that it suggests other states, especially the United States, may be wise to pay more attention to Chinese leaders' domain of actions during foreign policy crises. Chinese leaders' domain of actions can be influenced by both domestic and international factors. Foreign policy and diplomacy play an important role in boosting and strengthening Chinese leaders' domestic legitimacy. It explains why Xi has travelled overseas so frequently after he came to power. Xi has visited ten countries on four continents and attended nine international conferences. Xi made eight overseas trips in 42 days in 2015 (Yuan, 2015). 
Diplomatic successes, especially with other great powers, have become a useful tool for Chinese leaders to strengthen their political legitimacy at home. On the other hand, a foreign policy failure or disaster might shake their political status in the society and the CCP. Chinese leaders, including $\mathrm{Xi}$, are more likely to de-escalate a crisis or seek accommodation when they feel confident. If they feel cornered by either domestic rivals or international adversaries, Chinese leaders are more likely to escalate a crisis as a means to regain weakened political power and status. If the rise of China is an inevitable challenge to the international system, how to understand and manage China's crisis behaviour is an imperative task for policy makers in the $21^{\text {st }}$ century. However, it is also important to understand that it can be very risky to meddle in the power struggle inside the CCP. Because of the historical memory of 'one hundred years of humiliation' from Western aggression, any foreign interference in domestic affairs will likely trigger strong nationalism from Chinese society and consequently encourage Chinese leaders to choose more assertive and hardline policies. 
Table 1. Multiple Comparisons of P4 (Historical Control) across Four Periods for Xi

Dependent Variable: P4 Belief

Tukey HSD

\begin{tabular}{|c|c|c|c|c|c|c|}
\hline \multirow[b]{2}{*}{$\begin{array}{l}\text { (I) } 4 \\
\text { periods }\end{array}$} & \multirow[b]{2}{*}{ (J) 4 periods } & \multirow{2}{*}{$\begin{array}{c}\text { Mean } \\
\text { Difference } \\
(\mathrm{I}-\mathrm{J})\end{array}$} & \multirow[b]{2}{*}{$\begin{array}{l}\text { Std. } \\
\text { Error }\end{array}$} & \multirow[b]{2}{*}{ Sig. } & \multicolumn{2}{|c|}{ 95\% Confidence Interval } \\
\hline & & & & & $\begin{array}{l}\text { Lower } \\
\text { Bound }\end{array}$ & $\begin{array}{l}\text { Upper } \\
\text { Bound }\end{array}$ \\
\hline \multirow{3}{*}{$\begin{array}{l}\text { before } \\
2013\end{array}$} & 2013 & -.06708 & .03005 & .125 & -.1462 & .0120 \\
\hline & 2014 & $-.11474^{*}$ & .02369 & .000 & -.1771 & -.0524 \\
\hline & 2015 & $-.08308^{*}$ & .02566 & .010 & -.1506 & -.0155 \\
\hline \multirow[t]{3}{*}{2013} & before 2013 & .06708 & .03005 & .125 & -.0120 & .1462 \\
\hline & 2014 & -.04767 & .03103 & .422 & -.1294 & .0340 \\
\hline & 2015 & -.01600 & .03255 & .961 & -.1017 & .0697 \\
\hline \multirow[t]{3}{*}{2014} & before 2013 & $.11474^{*}$ & .02369 & .000 & .0524 & .1771 \\
\hline & 2013 & .04767 & .03103 & .422 & -.0340 & .1294 \\
\hline & 2015 & .03167 & .02680 & .640 & -.0389 & .1022 \\
\hline \multirow[t]{3}{*}{2015} & before 2013 & $.08308^{*}$ & .02566 & .010 & .0155 & .1506 \\
\hline & 2013 & .01600 & .03255 & .961 & -.0697 & .1017 \\
\hline & 2014 & -.03167 & .02680 & .640 & -.1022 & .0389 \\
\hline
\end{tabular}

* The mean difference is significant at the 0.05 level. 
Table 2: A Comparison of the P-4 Operational Code of Hu Jintao between 2011 and 2012 (before and during the 2012 crises)

ANOVA Test
P-4 Operational Code Belief
\begin{tabular}{|l|r|r|r|r|r|}
\hline & $\begin{array}{r}\text { Sum of } \\
\text { Squares }\end{array}$ & df & Mean Square & F & Sig. \\
\hline $\begin{array}{l}\text { Between Groups } \\
(2011 \text { vs. 2012) } \\
\text { Within Groups } \\
\text { Total }\end{array}$ & .077 & 1 & .077 & 11.267 & $\mathbf{. 0 0 4}$ \\
\hline
\end{tabular}

* Significant level at $\mathrm{P}<.05$ level (two-tailed test)

\section{Notes:}

${ }^{1}$ Our use of 'crisis' follows the tradition established by C. Hermann (1969) and Brecher and Wilkenfeld (2000) who identify threat, surprise, and short response time as key elements of a conflict situation. Others have emphasised one or more of these traits to distinguish between 'near crises' and 'military crises,' based on whether the threat is diplomatic or military, and between 'foreign policy' vs. 'international' crises, depending on whether one or both parties in a conflict situation perceive the other as a threat. Since we are focused on only one of the antagonists (China), we refer to the diplomatic conflicts between the US and China as 'foreign policy crises' for China. The absence of immediate military conflict, surprise, and a short response time would prompt others to label these situations as 'near crises'.

${ }^{2}$ Prospect theory scholars normally use the status quo to set leaders' reference point and thereby measure the domain of actions. Here, we set the status quo of Chinese leaders' P-4 value as a reference point. Through measuring the changes of the P-4 operational code value before vs. during crises, we measure the leaders' domain of actions. For using the status quo to set the reference point, see McDermott (1998); Mercer (2005).

${ }^{3}$ Greenstein (1987), Holsti (1976), and M. Hermann (1974) identify a leader's strategic position at the apex of a decision-making unit as one of the conditions in which the leader's personality (including beliefs) are likely to be indispensable in explaining a decision. Other conditions include the stress of a conflict situation and the need to make a decision within a finite period, e.g., within a crisis situation. Our focus here is on situations that meet wholly or partly these three conditions as a 'near crisis' foreign policy situation (see fn. 1 above).

${ }^{4}$ They also use P-1 and P-2 operational code beliefs in their research. There are two reasons for us not to use other operational code beliefs, such as P-1, P-2, or I-3, in this research. First, we would like to highlight the most important belief in measuring the domain of actions as either gains or losses specified by prospect theory. Second, P-4 as a key belief is measured partly as an integrated aggregation of the other key philosophical and instrumental beliefs; the denominator of the P-4 index is the sum of the denominators for P-1 and I-1 as the other two key beliefs (see Schafer \& Walker, 2006a, pp. 25-54). 


\section{References:}

Achen, C. (1988). A state with bureaucratic politics is responsible as a unitary actor. Presented at the Annual Meeting of the American Political Science Association, September 1-4, Washington DC.

Brecher, M., \& Wilkenfeld, J. (2000). A study of crisis. Ann Arbor: University of Michigan Press.

Buckely, C. (2017). Xi Jinping unveils China's new leaders but no clear successor. New York Times, October 24.

Dibb, P. (2015). Not so scary: This is why China's military is a paper tiger. The National Interest, October 15.

Economy, E. (2014). China's imperial president: Xi Jinping tightens his grip. Foreign Affairs, 93(6), 80-91.

Erickson, A. S., \& Liff, A. P. (2016). Installing a safety on the 'loaded gun'? China's institutional reforms, National Security Commission and Sino-Japanese crisis (in)stability. Journal of Contemporary China, 25(98), 197-215.

Feng, H. (2005). The operational code of Mao Zedong: Defensive or offensive realist? Security Studies, 14(4), 637-662.

Fravel, M. T. (2008). Strong borders, secure nation: Cooperation and conflict in China's territorial disputes. Princeton: Princeton University Press.

George, A. (1969). The 'operational code': A neglected approach to the study of political leaders and decision-making. International Studies Quarterly, 13(2), 190-222.

Greenstein, F. (1987). Personality and politics. Princeton, NJ: Princeton University Press.

He, K. (2016). China's crisis behavior: Political survival and foreign policy. Cambridge: Cambridge University Press.

He, K., \& Feng, H. (2011). Deceptive bargaining and nuclear ambitions: Prospect theory and North Korea's decision to go nuclear. In S. Walker, A. Malici \& M. Shafer (Eds.), Rethinking foreign policy analysis (97-111). New York: Routledge.

Hermann, C. (1969). Crises in foreign policy. Indianapolis, IN: Bobbs-Merrill.

Hermann, M. (1974). Leader personality and foreign policy behaviour. In J. Rosenau (Ed.), Comparing foreign policies (201-234). New York: John Wiley. 
Hohammed, A., \& Wu, J. R. (2016). U.S. expects 'very serious' talks with China after missile reports. The Reuters, February 17.

Holsti, O. R. (1976). Foreign policy viewed cognitively. In R. Axelrod (Ed.), The structure of decision (18-54). Princeton, NJ: Princeton University Press, pp..

Holsti, O. R. (1977). The 'operational code' as an approach to the analysis of belief systems. Final Report to the National Science Foundation, grant SOC75-15368.

Hu, W. (2016). Xi Jinping’s ‘big power diplomacy’ and China’s Central National Security Commission (CNSC). Journal of Contemporary China, 25(98), 163-177.

ICG (The International Crisis Group). (2012). Stirring up the South China Sea (I). Asia Report No. 223, April 23.

Jakes, S. (2016). Visualizing China's anti-corruption campaign. ChinaFile.com, January 21.

Jakobson, L. (2014). China's unpredictable maritime security actors. Sydney: Lowy Institute for International Policy.

Kahneman, D., \& Tversky, A. (1979). Prospect theory: An analysis of decision under risk. Econometrica, 47(2): 263-291.

Keck, Z. (2014). China's President is a paper tiger. The Diplomat, September 18.

Kuhn, R. L. (2010). How China's leaders think. Singapore: John Wiley \& Sons.

Lague, D., Kim, B. K., \& Zhu, C. (2014). Special report: Fear and retribution in Xi's corruption purge. Reuters.com, December 23.

Lam, W. (2015a). Is Xi Jinping a paper tiger? The Voice of Hong Kong, November 24.

Lam,W. (2015b). Chinese politics in the era of Xi Jinping. London: Routledge.

Landler, M. (2014). On a trip that avoids Beijing, Obama keeps his eye on China. The New York Times, April 26.

Leites, N. (1951). The operational code of the Politburo. New York: McGraw Hill.

Leites, N. (1953). A study of Bolshevism. New York: Free Press.

Levy, J. (1996). Loss aversion, framing, and bargaining: The implications of prospect theory for international conflict. International Political Science Review, 17(2), 179-195.

Levy, J. (1997). Prospect theory, rational choice, and international relations. International Studies Quarterly, 41(1), 87-112.

Lyle, A. (2014). DoD registers concern to China for dangerous intercept. DoD News, August 24. 
MacFarquhar, R. (2015). China: The superpower of Mr. Xi. The New York Review of Books, August 13.

Malici, A., \& Malici, J. (2005). The operational codes of Fidel Castro and Kim Il Sung: The last cold warriors? Political Psychology, 26(3), 387-412.

Marfleet, G. (2000). The operational code of John F. Kennedy during the Cuban Missile Crisis: A comparison of public and private rhetoric. Political Psychology, 21(3), 545-558.

McDermott, R. (1998). Risk-taking in international relations: Prospect theory in post-war American foreign policy. Ann Arbor: University of Michigan Press.

Mercer, J. (2005). Prospect theory and political science. Annual Review of Political Science, 8, $1-21$.

Neuman, S. (2012). Little islands are big trouble in the South China Sea. September 7. Retrieved from www.npr.org.

Pei, M. (2014). Explaining the P-8 incident: Are Chinese pilots going 'rogue'? The National Interest, September 3.

Perlez, J. (2012a). Beijing exhibiting new assertiveness in South China Sea. The New York Times, May 31.

Perlez, J. (2012b). Dispute between China and Philippines over island becomes more heated. The New York Times, May 10.

Perlez , J., \& Bradshermay, K. (2014). In high seas, China moves unilaterally. The New York Times, May 9.

Perlez, J., \& Hernández, J. C. (2015). U.S. tells Asian allies that navy will patrol near islands in South China Sea. The New York Times, October 12.

Phillips, T. (2017). Xi Jinping becomes most powerful leader since Mao with China's change to constitution. The Guardian, October 24. Retrieved from https://www.theguardian.com/world/2017/oct/24/xi-jinping-mao-thought-on-socialismchina-constitution.

Qin, Y. (2014). Continuity through change: Background knowledge and China's international strategy. The Chinese Journal of International Politics, 7(3), 285-314.

Rauhala, E., \& Xu, Y. (2016). Chinese website publishes, then pulls, explosive letter calling for President Xi’s resignation. Washington Post, March 16. 
Reuters. (2014). Three major nations absent as China launches World Bank rival in Asia.

November 5. Retrieved from http://www.reuters.com/article/2014/11/05/us-china-aiibidUSKCN0ID08U20141105

Schafer, M., \& Walker, S. (Eds.). (2006a). Beliefs and leadership in world politics. New York: Palgrave.

Schafer, M., \& Walker, S. (2006b). Democratic leaders and the democratic Peace: The operational codes of Tony Blair and Bill Clinton. International Studies Quarterly, 50(3), $561-583$.

Schafer, M., Robison, S., \& Aldrich, B. (2006). Operational codes and the 1916 Easter Rising in Ireland: A test of the frustration-aggression hypothesis. Foreign Policy Analysis, 2(1), $63-82$.

Singh, M. (2016). China's Middle East tour: Beijing's post-sanctions ambitions. Foreign Affairs, January 24.

Sutter, R., \& Huang, C-H. (2012). China-Southeast Asia relations: China gains and advances in South China Sea. Comparative Connections, 14(3), 69.

Swaine, M. (2015a). Chinese views and commentary on the 'One Belt, One Road' initiative. China Leadership Monitor, 47, 124.

Swaine, M. (2015b). Xi Jinping on Chinese foreign relations: The governance of China and Chinese commentary. China Leadership Monitor, 48, 1-13.

Taliaferro, J. W. (2004). Balancing risks: Great power intervention in the periphery. Ithaca, NY: Cornell University Press.

The Economist. (2013a). Dangerous Shoals. January 19.

The Economist. (2013b). China and Japan: Locked on. February 9.

The Straits Times. (2014). Obama says China's Xi has consolidated power quickly, worrying neighbours. The Straits Times, December 4.

Walker, S. (1977). The interface between beliefs and behaviour: Henry Kissinger's operational code and the Vietnam War. Journal of Conflict Resolution, 21(1), 129-168.

Walker, S. (1983). The motivational foundations of political belief systems: A re-analysis of the operational code. International Studies Quarterly, 27(2), 179-202. 
Walker, S. (2011). Foreign policy analysis and behavioral international relations. In S. Walker, A. Malici \& M. Schafer (Eds.), Rethinking foreign policy analysis (3-20). London: Routledge.

Walker, S., \& Schafer, M. (2010). Operational code theory. In R. Denemark (Ed.), The international studies encyclopedia, vol. 8 (5494-5514). Chichester, UK: WileyBlackwell.

Walker, S., Schafer, M., \& Young, M. (1998). Systematic procedures for operational code analysis: Measuring and modeling Jimmy Carter's operational code. International Studies Quarterly, 42(1), 175-189.

Walker, S., Shafer, M., \& Young, M. (2003). Profiling the operational codes of political leaders. In J. M. Post (Ed.), The psychological assessment of political leaders: With profiles of Saddam Hussein and Bill Clinton (215-245). Ann Arbor: University of Michigan Press.

Wen, P., \& Murdoch, L. (2016). China dismisses concern over South China Sea missiles deployment. The Sydney Morning Herald, February 17.

Wilkenfeld, J. (2006). Concepts and methods in the study of international crisis management. In M. D. Swaine \& Z. Tuosheng (Eds.), Managing Sino-American crises: Case studies and analysis (103-132). Washington, DC: Carnegie Endowment for International Peace.

Yan, X. (2014). From keeping a low profile to striving for achievement. The Chinese Journal of International Politics, 7(2), 153-184.

You, J. (2016). China's National Security Commission: Theory, evolution and operations. Journal of Contemporary China, 25(98), 178-196.

Yuan, C. (2015). 2015 in review: Xi Jinping's diplomatic trip in 42 days. People's Daily, December 8. 